\title{
ACESSO À JUSTIÇA: PERSPECTIVAS CRÍTICAS A PARTIR DA JUSTIÇA COMUNITÁRIA ANDINA $^{*}$
}

\author{
Access to justice: critical perspectives from the \\ andean community justice
}

\author{
Jackson da Silva Leal ** \\ Lucas Machado Fagundes ***
}

\section{RESUMO}

Propõe-se o tema do acesso à justiça a partir do viés crítico, passando pela democratização da administração da justiça e o reconhecimento de um contexto de Pluralismo Jurídico de tipo comunitário participativo. Apresentam-se as experiências de Justiça Comunitária de países, como Colômbia e Peru, e uma análise da Justiça Restaurativa, em um contexto de reflexão crítica das formas de acesso à justiça, em uma perspectiva de quebra do paradigma do direito tradicional moderno. Trabalha-se com a descolonialidade do pensamento latino-americano, destacando-se a importância da ideia de acesso para além dos tribunais, em um processo de recomposição dos laços sociais e da (re)criação da identidade e do sentimento de pertença.

Palavras-chave: Acesso à justiça. Pluralismo jurídico. Justiça comunitária.

* O presente trabalho foi realizado com o apoio da Coordenação de Aperfeiçoamento de Pessoal de Nível Superior (Capes).

** Mestrando em Politica Social (UCPel); graduado em Direito (UCPel); advogado inscrito na $\mathrm{OAB} / \mathrm{RS}$; bolsista pesquisador Capes; membro do Núcleo de Estudos e Pesquisa em Questao Social, Acesso à Justiça e Direitos Humanos. Contato: jacksonsilvaleal@gmail.com

*** Doutorando em Direito (UFSC), mestre em Direito (UFSC); graduado em Direito (UCPel). Contato: lucas-sul@hotmail.com 


\begin{abstract}
It is proposed that the issue of access to justice from the critical bias, through the democratization of the administration of justice and recognition of a context of legal pluralism type participatory community. It presents the experiences of Community Justice of countries such as Colombia and Peru and an analysis of restorative justice in the context of a critical reflection on ways of access to justice, from the perspective of breaking the modern paradigm of traditional law. We work with the Latin American colonial thought, highlighting the importance of the idea of access beyond the courts in a process of reconstruction of social ties and the (re) creation of identity and sense of belonging.
\end{abstract}

Keywords: Access to justice. Legal pluralism. Community justice.

\title{
INTRODUÇÃO
}

Este estudo explora, de forma crítica, por meio da temática do acesso à justiça, as experiências de justiça comunitária em contexto, como a dos países andinos, em destaque para a Colômbia e o Peru. Tal trabalho consiste em uma pesquisa teórica que irá debater as formas, tipos e mecanismos de justiça comunitária e sua inserção na discussão com tradicionais formas de juridicidade.

Dessa forma, vamos problematizar a temática proposta partindo da lógica de crise da cultura jurídica monista e do racionalismo positivista estatal, traçando um viés de acesso desde o âmbito de ingerência estatal até os modelos comunitários, explorando a crise de juridicidade, embasados pela teoria de um pluralismo jurídico de tipo comunitário participativo, procurando destacar as categorias em que se produz o empoderamento popular por meio da democracia participativa comunitária e a produção de um direito insurgente na busca de (re)criação da identidade e de um sentimento de pertença comunitária.

Enfim, dialogar de forma reflexiva sobre a situação de interação entre Estado, mercado e cidadão, observando sua influência na administração da justiça, buscando salientar a necessidade de ampliar seus espaços de participação, para, por meio da justiça comunitária, intentar a reconstrução de uma identidade emancipatória e a recomposição dos laços comunitários esfacelados pelo individualismo exacerbado 
e concorrencial das concepções políticas neoliberais; uma busca pela democratização de um espaço historicamente negado aos populares e às comunidades periféricas em relação aos poderes e às instituições centrais que hoje se encontram em crise.

\section{PROBLEMATIZANDO O ACESSO À JUSTIÇA: DA ORDEM ESTATAL PLURAL AO PODER CO- MUNITÁRIO, EMPODERAMENTO POPULAR E CRIAÇÃO DE RESISTÊNCIA}

Inicialmente, cabe referir que este estudo comporta uma análise crítica do processo de acesso à justiça, entendida, aqui, a partir de uma ordem justa e igualitária de acesso aos bens materiais e imateriais de vivência digna, diga-se vivência dentro das condições sanitárias, morais, educacionais, habitacionais, somada a um contexto de participação política efetiva numa democracia de alta intensidade. ${ }^{1}$

Torna-se inegável a necessidade de explorar o contexto de crise do direito como resultado da sua insuficiência em sociedades e realidades, como a latino-americana, fazendo aporte a uma crítica mais ampla ao sistema capitalista e à sua redução humanitária às relações de consumo. Para estudar e mesmo criticar o direito e o sistema de justiça tradicional, precisamos ter clara essa situação, para a qual Wolkmer dirá:

As atuais sociedades de massa integrantes do centro e da periferia capitalista passam por novas e flexíveis modalidades de produção do capital, por radicais contradições sociais e por instabilidades continuadas que refletem crises, tanto em nível de legitimidade, quanto de produção e aplicação da justiça. Ademais, importa enfatizar que o esgotamento do modelo jurídico tradicional não é a causa, mas o efeito de um processo mais abrangente que reproduz a transformação estrutural por que passa o sistema produtivo do Capitalismo global, quanto expressa a crise cultural valorativa que atravessa as formas de fundamentação dos diferentes setores das ciências humanas. ${ }^{2}$

Dessa forma, para além da concepção tradicional de acesso aos meios jurídicos estatais, pugnamos por outra leitura, uma leitura crítica da temática, problematizando o próprio acesso à justiça em seu âmago, a busca de produção de outro direito, de concepções pluralistas 
comunitárias e participativas em processos de produção de autonomia e identidade, num sentido de descolonizar o pensamento jurídico de base eurocêntrica.

Assim, a partir do pensamento de um acesso à participação e a formação de uma justiça comunitária, procuramos discutir o direito, a política e a sociedade por um viés que conduza à revolução nos "cânones hegemônicos" político e jurídico, por entender que o próprio processo de reforma pelo qual passam os países latino-americanos, principalmente o Brasil, é apenas amenizador dos reais problemas sociais que eles vivem. Maquiar a crise do direito ou mesmo sustentar seus mitos ${ }^{3}$ não fazem parte da agenda crítica e insurgente.

Contudo, não podemos esquecer que o nosso objetivo é a busca de uma "revolução democrática da justiça", parafraseando o título da obra de Boaventura Sousa Santos, na qual menciona que tradicionalmente os tribunais não foram feitos para atender às demandas da camada pobre da população, e nem mesmo essa vê nos tribunais um meio confiável para resolver suas demandas. Por quê?

Porque os tribunais não foram feitos para julgar para cima, isto é, para julgar os poderosos. Eles foram feitos para julgar os de baixo. As classes populares, durante muito tempo, só tiveram contacto com o sistema judicial pela via repressiva, como seus utilizadores forçados. Raramente o utilizaram como mobilizadores ativos. A questão da impunidade está inscrita na própria matriz do Estado liberal que, como se sabe, não é um Estado Democrático em sua origem. ${ }^{4}$

Apesar dessa situação, os movimentos sociais e as camadas populares, a partir das reformas judiciais e da proliferação de juizados especiais, começaram, na busca por suas demandas, a abandonar a ilegalidade e utilizar as ferramentas jurídicas, o que, de imediato, instaura outro problema, que Boaventura Sousa Santos ${ }^{5}$ denomina de "demanda suprimida", e esta não pode ser resolvida nos tribunais, pois faz parte de um processo de transformação e não de reforma. $\mathrm{O}$ autor menciona que tal demanda suprimida

É a procura daqueles cidadãos que têm consciência dos seus direitos, mas que se sentem totalmente impotentes para os reivindicar quando 
são violados [...]. Ficam totalmente desalentados sempre que entram no sistema judicial, sempre que contactam com as autoridades, que os esmagam pela sua linguagem esotérica, pela sua presença arrogante, pela sua maneira cerimonial de vestir, pelos seus edifícios esmagadores, pelas suas labirínticas secretarias etc. ${ }^{6}$

Na sequência da leitura, o mesmo autor irá mencionar que, para atender a essa exigência suprimida, necessitamos de um processo de revolução cultural no direito. Colocamos que esse processo de pensar uma nova cultura jurídica para de fato acessarmos uma ordem justa, um acesso à justiça social, passa pela formação de uma nova mentalidade jurídica, descolonizada e liberta dos dogmas e mitos jurídicos iluministas burgueses. ${ }^{7}$ Santos propõe:

Mas, é preciso termos a noção da exigência que está pela frente. Para satisfazer a procura suprimida são necessárias profundas transformações do sistema judiciário. Não basta mudar o direito substantivo e o direito processual, são necessárias muitas outras mudanças. Está em causa a criação de uma outra cultura jurídica e judiciária. ${ }^{8}$

Diante disso, analisar e destacar as peculiaridades das políticas de justiça comunitária de países como Colômbia e Peru traduz uma maneira diferenciada e que talvez possa trazer uma leitura também diferenciada da temática. Estudiosos, como Mauro Cappelletti e Bryant Garth," autores do famoso livro "Acesso à Justiça", trazem o histórico de prestações jurisdicionais no cabresto do direito e das instituições moderno-iluministas. Para um projeto de emancipação latino-americana, devemos, antes de pensar em acessar o direito posto, questionar a própria legitimidade da produção desse direito e da justiça, ponderando pelas exigências de justiça que advêm das comunidades periféricas (do poder hegemônico).

Assim, Boaventura Sousa Santos nos demonstra a inadequação de um acesso à justiça que não tenha uma leitura intercultural, que venha dessa ideia engessada de direito na realidade plural latino-americana, mencionando um caso ocorrido em sala de aula na Colômbia:

Era indígena e freqüentava o primeiro ano da Faculdade de Direito da Universidade Nacional da Colômbia em Bogotá. Numa aula de direito 
civil, em que o professor leccionava que a terra é um objecto de propriedade, que se compra e se vende, ela pediu pra falar e disse: 'mas professor, na minha comunidade não é assim, nós não podemos possuir a terra porque nós somos parte da terra, a terra não nos pertence, nós é que pertencemos à terra'. Ao que o professor respondeu rispidamente: 'eu estou aqui a ensinar o código civil, não me interessam outras concepções'. Ela chegou ao meu gabinete a chorar porque o conhecimento jurídico oficial que ela estava aprendendo esta a torná-la ignorante a respeito do seu próprio direito indígena. Ao aprender o direito oficial, estava a esquecer activamente o direito indígena, e, portanto, o processo de conhecimento era também um processo de desconhecimento ${ }^{10}$.

Dessa maneira, a busca por justiça, dentro dos marcos legais estatais, deve ser problematizada por um processo local e comunitário de reconhecimento de uma identidade e de uma produção autônoma. Tais realidades periféricas não se sentem voluntariamente abrangidas em suas necessidades pelo direito posto. A busca dentro das lógicas positivas é um jogo complexo e de difícil compreensão para os núcleos populares. Suas facetas, detalhes e arquitetura são algo longe de suas realidades. Vale novamente mencionar o professor Wolkmer no sentido,

Delante de esto, las prácticas democráticas han adquirido mayor legitimidad comunitaria, reflejando los intereses y los conflictos de las diversas fuerzas sociales del cotidiano local. Se trata de la práctica de la justicia marcada por la fluidez y porosidad porque, al estar en permanente cambio, aglutina alredor de las cuestiones específicas y en el momento exacto, los intereses que son sentidos por la comunidad. ${ }^{11}$

Finalizando esta parte inicial, destacamos que empoderamento popular consiste na tomada de consciência da capacidade e articulação que os núcleos populares possuem para dominar e resolver suas próprias desavenças. Em muitos casos, a ingerência estatal provocaria maiores danos; ao contrário, se a divergência fosse resolvida pelos mecanismos e agentes intermediários ${ }^{12}$ da própria comunidade, a situação teria um trabalho de resolução mais eficaz.

Por fim, problematizar o acesso à justiça significa nos libertarmos inicialmente das concepções monistas e entender que a justiça também se faz fora dos âmbitos estatais e de forma mais eficaz, e também reconhecer que o direito e suas facetas liberais se encontram em crise e 
não traduzem, quiçá nunca traduziram, os anseios dos povos daqui. Como muita coisa na América Latina, o direito e as instituições jurídicas também são de origem do colonizador europeu. As questões referentes ao empoderamento e ao surgimento de um direito insurgente, ${ }^{13}$ dentro do contexto de pluralismo jurídico, passam pela leitura crítica de nossa sociedade, pela releitura da cidadania submetida à tríade Estado-Mercado-Cidadão, culminando com a democratização da administração da justiça, numa percepção de uma produção normativa advinda dos próprios núcleos comunitários. Essas formas iremos encontrar nos fortes movimentos de justiça comunitária de países andinos, como Colômbia e Peru, práticas que vamos estudar com mais detalhes na segunda parte deste trabalho.

\section{ENCONTRO DE VETORES: O DIÁLOGO ENTRE ES- TADO, MERCADO E COMUNIDADE, PARA QUAL CIDADANIA?}

Neste ponto do trabalho, necessário se fazem alguns apontamentos do contexto moderno em que se insere a América Latina, entre o mercado e um Estado que atua a partir de densa dinâmica heterônoma.

Assim, insta trazer alguns vetores que confluem para o desmanche do diálogo intercultural e identitário, vital para a manutenção e defesa da cultura e alteridade propriamente latino-americanas, bem como de uma potencialidade insurgente acompanhada de uma vida digna de ser vivida.

Gostaríamos de apresentar alguns vetores que envolvem e permeiam a sociedade e a sua cultura, o mercado e algumas de suas dinâmicas modernas e o Estado e sua juridicidade. Esses três vetores são legitimados e ontologizados por um paradigma científico que os justifica, hegemoniza e, assim, legitima os envolvidos nessa lógica, a sociedade.

No plano da sociedade e sua carga cultural, é importante frisar que a historicidade latino-americana é marcada por processos de colonização e saber-poder hegemônico que desintegram e brutalizam a cultura típica e própria dos povos locais; que sofreram e sofrem histórica e constantemente um processos de desconstituição identitária. Uma das 
estratégias modernas para tal tarefa/ propósito é a homogeneização dos saberes/identidades/discursos que se fundem em prol da dinamização do capital e de suas necessidades de demanda consumidora, que não são meramente materiais, mas também de identidades e ideologia, uma subjetivação moderno-capitalista comprada e a alto custo.

No mesmo sentido, seguindo no plano do mercado, deve-se pontuar uma das principais características que possibilitam a perpetuação desse paradigma ocidental global, que é a fragmentação social e o consequente enfraquecimento do processo de contestação político-social, que culmina com a manutenção da dinâmica estruturada e estruturante ocidental burguesa. Somando-se a redução drástica das relações humanas às relações de consumo, que, legalizadas pelas normatividades humanitárias, sofrem a redução às lógicas mercadológicas que impõem sua hegemonia; na contramão disso, pautamo-nos por uma filosofia transformadora e problematizamos o sujeito coisificado e imerso nessa lógica hegemônica,

A lógica da constituição do sujeito, da liberdade do contrato, da autonomia da vontade, da igualdade entre os contratantes, tendo por início a necessidade própria circulação mercantil capitalista, ilumina a explicação a respeito da origem dos direitos humanos. Antes de serem conquista da bondade humana ou da revolução do espírito, são necessidades práticas da exploração capitalista, razão pela qual tais instâncias jurídicas tendem a se afirmar universalmente - como universalmente se apresenta a reprodução da circulação mercantil. ${ }^{14}$

Na mesma linha, aborda-se o Estado que, permeado pela mesma dinâmica de universalidade e homogeneização, atua a partir de um ideário importado e a um alto custo político-social e cultural-identitário e que se produz com a diminuição ou estratificação dos espaços políticos de diálogo, deliberação e troca de saberes, que se tornam meros espaços ou comitês políticos de um pequeno grupo detentor do poder discursivo e decisório. Isso Bauman ${ }^{15}$ propõe como sendo a política vida que destrói os laços de intersecção entre a sociedade e a política.

No plano da juridicidade que é produzida ou que, em parte, é produtora dessa dinâmica eurocêntrica, verifica-se um processo de invisibilização de identidades e necessidades que se dá pela procedi- 
mentalidade kafkiana do Poder Judiciário e do poder de dizer o direito de forma autoritária e com uma pretensa ideia messiânica de resolução de conflitos, ao menos discursiva e ficticiamente, não respeitando ou levando em conta as vozes e saberes dos direta e indiretamente envolvidos no conflito, que ficam imersos e sufocados pelas decisões abstratas e desinteressadas da justiça hegemônica e seu ideário descontextualizado e dissociado da realidade em que se insere e deforma.

Por fim, todo este ideário político-social-cultural é justificado e legitimado, construído e sedimentado por e sobre um paradigma epistemológico positivista que é artificialmente naturalizado, deificado, ontologizado. Paradigma este que é a história da construção de uma cientificidade hegemônica e burguesa, mas também é a trajetória da desconsideração e invisibilização da história, cultura, saberes e poderes de povos que foram definidos como bárbaros, incivilizados e tornados meros repositórios da cultura e da justiça dos outros, sem vez e voz, e não podendo tomar parte na resolução dos próprios conflitos e na direção da própria vida. Nessa linha, é elucidativa a colocação de Walter Mignolo:

A cumplicidade entre a modernidade e o conhecimento, auto-definida como um ponto de chegada planetário, foi ao mesmo tempo colonialidade enquanto negação epistêmica planetária. Hoje, a descolonização já não é um projecto de libertação das colônias, com vista à formação de Estados-nação independentes, mas sim o processo de descolonização epistêmica e de socialização do conhecimento. A diversidade epistêmica será o horizonte para o qual convergem o paradigma da transição. ${ }^{16}$

Para tentar romper com essa epistemologia eurocêntrica e hegemônica, é que este trabalho propõe a retomada de um pensamento e ação latino-americanos, remontando a um processo de sociabilidade calcado na produção e valorização identitária. Nesse sentido, vale trazer a contribuição de Boaventura de Sousa Santos, a partir de uma analise de topói indígena:

Al contrario, desde la visión indígena, la sociedad es una sola, la economía es una sola y la lógica política es igualmente una sola. Para los indígenas, la cultura es todo y por eso el diálogo intercultural no es imaginable si no se respeta la diversidad en lo que la cultura eurocéntrica llama lo económico (la vida) y lo político (el control del territorio). ${ }^{17}$ 
Pautando-se na fuga dessa lógica, que engole a sociedade globalizada, os núcleos de justiça comunitária buscam reafirmar seus laços de sociabilidade a partir da administração de sua própria justiça como forma de enfrentamento e resistência, reinventando o conceito de cidadania individualista liberal que rege esse contexto de isolamento do conflito na esfera da judicialidade estatal, para uma cidadania calcada na participação comunitária e no conflito como interesse de todos.

Assim, atua também na busca de superar a crise epistemológica do Estado moderno, voltando-se para uma leitura plural, de descentralização de poder, a partir da crítica insurgente e não das exigências mercadológicas. Elementos que serão trabalhados em seguida.

\section{PLURALISMO JURÍDICO COMUNITÁRIO PARTI- CIPATIVO E DESCENTRALIZAÇÃO DA ADMINIS- TRAÇÃO DA JUSTIÇA}

As diversidades culturais e jurídicas geram, em contextos latino-americanos, somadas a crise do ideal jurídico iluminista, a necessidade de produção insurgente às margens do direito oficial, um direito e uma justiça autônoma, voltados aos interesses e às particularidades de comunidades historicamente negadas em suas necessidades fundamentais e sonegadas em seus direitos. Assim, devemos somar o ímpeto participativo e comunitário na produção de emancipação, fator que pode ser embasado num pluralismo jurídico comunitário e participativo. $^{18}$

Tal acepção está no interior da crítica jurídica. O modelo jurídico tradicional e obsoleto não encontra mais guarida na realidade social e suas instituições representam o objeto da revolução democrática participativa da justiça. A administração da justiça passa pela problematização do contexto de crise, portanto opções tomadas deverão mexer nas bases do Estado moderno e nas raízes da colonização latino-americana. Para Wolkmer, a situação é posta da seguinte forma,

Ora, a problematização no que diz respeito se há ou não 'Direito sem positividade', e/ou se a 'positividade só resulta do Estado', encontra respostas diferentes em duas tendências tradicionalmente antagônicas: o monismo e o pluralismo jurídico. Não obstante algumas interpretações 
mais atenuantes, a rigor o monismo jurídico consagra que todo o Direito é a criação do Estado e, por conseguinte, todo Direito Estatal é Direito Positivo. A positividade, enquanto processo de formulação, generalidade e validade objetiva, é o traço essencial do Direito Estatal. Por outro lado, o pluralismo jurídico não só deixa de associar o Direito com o Direito positivo, como, sobretudo, admite a existência do Direito sem Estado. ${ }^{19}$

Desse modo, interessa-nos explorar a crise da juridicidade, como forma de descentralizar a administração da justiça, retirando o privilégio de controle das mãos do Estado para dividir com a comunidade a ingerência em tais procedimentos. Isso representa a quebra de paradigmas no direito moderno e passa a questionar a própria postura do Estado em frente a um contexto de emergente democracia em alta intensidade, ${ }^{20}$ no qual a participação comunitária se torna um novo marco político, e as exigências de sociedades plurais põem em questão a superação do velho modelo dogmático jurídico e sua crise epistemológica. ${ }^{21}$

Nesse contexto, emerge a necessidade da leitura do pluralismo jurídico. Assim, destacar sua importância em sociedades como a nossa, o reconhecimento de tal situação pelo Estado, quando da constitucionalização de meios alternativos de resolução de conflitos, como ocorre na Colômbia, é nada mais que a busca de alternativas diante da situação de crise do direito e da justiça, a pluralidade dividida em estatal e comunitária. A primeira, o reconhecimento e execução de uma justiça alternativa pelo Estado, e a segunda de origem e desenvolvimento pelos agentes da comunidade representam um importante passo para contornar os velhos paradigmas em crise.

Optar pela segunda parte da própria escolha política por um contexto de refundação das instituições democráticas que, para o contexto latino-americano, é parte de um processo de descolonização; assim, a agenda política pluralista é bastante ampla, fator que nos põe o risco de cair em engodos (neo)liberais ou falsos paradigmas reformistas, para nos manter dentro do mesmo projeto em crise e de racionalidade hegemônica. Novamente afirmamos o pensamento de Wolkmer:

[...] deste modo, a proposta de um novo pluralismo jurídico (designado de comunitário-participativo) configurado através de um espaço público aberto e compartilhado democraticamente, privilegiando a participa- 
ção direta de agentes sociais na regulação das instituições-chave da Sociedade possibilitando que o processo histórico se encaminhe por vontade e sob controle das bases comunitárias. ${ }^{22}$

Em razão desses fatores, devemos ficar atentos à ingerência do Estado. Já referimos acima que, para pensarmos uma nova ideia de direito e justiça, necessariamente, devemos nos libertar das velhas doutrinas jurídicas. A ruptura na mentalidade monista e positivista é um importante obstáculo a ser superado:

Naturalmente, na advertência de Yrigoyen Fajardo, 'a resistência da mentalidade monista, monocultural e racista dos operadores jurídicos e políticos [...] constitui uma barreira importante para a efetiva vigência do reconhecimento do pluralismo legal e da construção de um Estado pluricultural'. De qualquer forma, urge 'a superação do conceito individualista, monocultural e positivista dos direitos humanos para, sobre a base da igual dignidade das culturas, abrir caminho para uma definição e interpretação intercultural dos direitos humanos' ${ }^{23}$

Com tais afirmações, é primordial dialogar sobre as formas de administração da justiça, ${ }^{24}$ numa busca de democratizar esse espaço para uma convergência ou ingerência popular participativa. $O$ direito vem da rua, assim como a sua exigência por justiça. A questão da segurança jurídica não é mais apenas assunto do Estado, bem como a ampliação da cidadania, que deve ser com ele questionada.

Dessa forma, anuncia-se qual objeto deve ser atacado na reivindicação de espaço para administrar a justiça de forma democrática e participativa. A centralização jurídica do Estado é o ponto de diálogo e, em razão disso, novamente alertamos para os perigos do pluralismo jurídico de base estatal. Nesse processo de discussão, as ingerências estatais e suas bases reformistas irão intentar a introdução de soluções pelas velhas e tradicionais culturas e instituições jurídicas. No entanto, o momento é propício para a busca incansável de novos espaços e novos horizontes de um direito insurgente e voltado aos interesses das coletividades historicamente sonegadas em suas demandas pelas necessidades fundamentais de sobrevivências, grupos excluídos e criminalizados.

Nesse processo de descentralização, apresentamos a justiça comunitária como alternativa. Ainda que ela possua formas muito próxi- 
mas de cooptação pelo Estado, esta representa em cenários, como o colombiano e o peruano, elementos substancialmente revolucionários que demonstram haver possibilidades de romper com velhos paradigmas jurídicos e criticar de forma construtiva, numa empreitada de buscar o novo a partir de um pensamento filosófico de base latino-americana.

Pautamos que a segurança jurídica só se justifica na confiança das comunidades, nas práticas de justiça legitimadas, não pela coação e sim por laços culturais de identificação e pertença comunitária. Essas práticas, que privilegiam a normatividade social e o contexto de vivência dos sujeitos envolvidos, com mais detalhes serão exploradas na segunda parte deste estudo. Importa destacar que a utilização política de tais experiências representa um instrumento eficaz na busca de alternativas à insuportável crise do direito e da justiça. Para Wolkmer,

Um conjunto de vestígios confirmam a implementação crescente de novos mecanismos de auto-regulação dos conflitos e de resolução dos interesses emergentes. $\mathrm{O}$ alargamento de fórmulas jurídicas mais flexíveis e eficazes permite, segundo Celso Campilongo, deixar de lado 'uma concepção meramente legalista da justiça' que identifica Direito com lei, possibilitando que a solução dos conflitos se efetive 'através de fórmulas inteiramente novas de negociação, mediação e arbitramento. Valendo-se de mecanismos informais, essas técnicas abandonam, de um lado, a racionalidade formal dos ordenamentos de inspiração liberal, e, de outro, recuperam uma práxis orientada pela racionalidade material dos interesses e valores em jogo' ${ }^{25}$

Dito isso, passaremos a analisar a importância da normatividade social e seu diálogo com a normatividade estatal para a construção de uma nova democracia da justiça.

\section{DEMOCRATIZAÇÃO DA JUSTIÇA: DA NORMATI- VIDADE ESTATAL À NORMATIVIDADE SOCIAL}

Na busca de democratizar o hierarquizado e burocratizado espaço jurídico estatal, pautamo-nos por um diálogo normativo em que o direito e a justiça possam iniciar uma caminhada de confluência e transformação radical. Ou seja, o reconhecimento da produção normativa além do Estado não basta, temos de ter sua efetividade levada para além da tutela 
estatal. Isso não significa o abandono imediato da normatividade do Estado, o que traria o caos, pelo contrário, pugnamos pela inter-relação de uma normatividade estatal e uma normatividade social.

Nesse sentido, a difícil tarefa visa a uma convergência de política jurídica participava e comunitária que busca debater com o Estado a legitimidade de suas ações em determinados contextos periféricos. Já mencionamos o caso em que Boaventura de Sousa Santos destacou o desencontro de normatividades que vivenciou em sala de aula a menina indígena na Faculdade de Direito da Colômbia.

Diante de tal situação, o caso da estudante de direito, seria mais eficaz a compreensão do direito a partir de um diálogo intercultural ${ }^{26}$ entre a normatividade social da comunidade indígena e o direito tradicional. Administrar a justiça é uma competência que cabe especificamente às comunidades em seus núcleos de justiça comunitária. Quando existe normatividade em determinados contextos sociais, existe ali a possibilidade para que tais comunidades exerçam a administração de seus conflitos e suas demandas. Isso se dá quando, organizados em núcleos comunitários, fomentam e exercitam a participação democrática e a organização política. Sendo assim, mais uma vez, vamos destacar as palavras de Edgar Ardila que referendam nossas ideias,

Dos tipos de reglas son reconocibles en la administración de justicia comunitaria. En primero lugar, las reglas generales que rigen los comportamientos de la comunidad. Son el marco referencial para la toma de decisiones comunitarias. Desde ella se toman decisiones de fondo. En segundo lugar están las normas que regulan las instituciones que gestionan las controversias. Son las reglas que establecen las figuras llamadas a tramitar los asuntos y los procedimientos mediante los cuales actúan y deciden. En la mayoría de las comunidades, carecen de texto escrito pero están presentes en los modos de vivir, en las costumbres, las tradiciones, los relatos y los mitos. ${ }^{27}$

Após expressarmos os pressupostos do pluralismo jurídico comunitário participativo nos marcos de um processo insurgente de democratização do acesso à justiça e da administração da justiça pelos núcleos populares por meio da justiça comunitária, vamos intentar delinear as especificidades de tais experiências no contexto latino-americano dos Andes, em especial, nas práticas de países como Co- 
lômbia e Peru, para os quais destacaremos os tipos, mecanismos e a importância da justiça comunitária para uma nova perspectiva (crítica) do acesso à justiça e a democratização da administração da justiça em um contexto de descolonialidade.

\section{JUSTIÇA COMUNITÁRIA: OS TIPOS, MECANIS- MOS E EXPERIÊNCIAS DO CONTEXTO ANDINO}

Após problematizarmos o contexto de crise do direito e da justiça, afirmando nosso embasamento teórico no pluralismo jurídico comunitário participativo como forma de democratizar a administração da justiça, vamos trabalhar a justiça comunitária e suas formas de manifestação na realidade andina.

Sendo assim, cabe destacar que aos núcleos comunitários importa, além da satisfação das partes e a resolução do conflito, reativar as relações comunitárias feridas. A questão envolve uma noção de abrangência de toda a comunidade, na medida em que uma parte dela está fraturada e deve ser resolvida para além do simples individualismo da questão. Ou seja, não basta dizer quem tem razão, não basta atribuir culpabilidade ou ordenar indenização a uma das partes, importa também que essas partes reatem suas relações amistosas e de sociabilidade. O autor colombiano Edgar Ardila nos fala que,

Cuando las parte sólo están relacionadas por el objeto de litigio, una decisión judicial puede ser un buen mecanismo para poner fin a un conflicto. Pero cuando las partes tienen un conjunto de relaciones que desbordan el objeto de la controversia, lo más posible es que un proceso judicial o una sentencia no sea realmente eficaz y que cauterizado uno de los focos del problema este haga metástasis en otros niveles. ${ }^{28}$

Para quem trabalha com justiça comunitária, a origem da discussão se traduz em que “[...] o problema não somos nós. O problema está no lugar onde sempre esteve desde seu nascimento, está na justiça liberal, seus saberes e suas práticas perversas indolentes frente ao sofrimento alheio. Aí está a questão inicial de uma ampla luta pela Justiça", ${ }^{29}$ fator que reforça a ideia de descolonizar e politizar a luta por um acesso à justiça de base comunitária e participativa num con- 
texto plural. Usando novamente as palavras do advogado boliviano Idón Moisés Chivi Vargas, sobre a jurisdição ordinária de um ponto de vista crítico,

Bolivia esta enfrentando un nuevo tiempo político, sin recetas de por medio, sabiendo que un Nuevo Estado es la base de un Nuevo Derecho y una Nueva institucionalidad. Bolivia esta enfrentando el reto de Descolonizar el Estado desde el Estado; Descolonizar el Derecho y la justicia. O se mantiene al "sistema judicial formal y ordinario" en calidad de rehén de los otros poderes o enfrentamos sinceramente el reto de su verdadera independencia política. ${ }^{30}$

Nessa empreitada, ao falarmos de justiça comunitária, utilizamos as palavras de seu maior expositor:

Concluimos, entonces, que se entiende por justicia comunitaria a un conjunto de instancias y procedimientos mediante los cuales, para situaciones de controversia, se regulan los comportamientos legítimos a partir de normas propias de una de una comunidad o contexto cultural específico. Es administración de justicia desde la comunidad, a partir de sus propias reglas y principios [...]. Es comunitaria en tanto su capacidad regulatoria deriva de dinámicas de identidad y pertenencia a lo mismo. La existencia de ese sentimiento de pertenencia es el puente que permite que los actos procedimentales y decisorios de estas instituciones de justicia interpelen de manera presente o diferida a los miembros de una comunidad. Tal sentimiento puede ser ocasionado por afectos o tradición. ${ }^{31}$

Fica evidente, na exposição acima, o protagonismo dos agentes da própria comunidade. Nessa denominação, a participação comunitária em termos de justiça e direito é de um tipo de pluralismo jurídico que já delineamos. Assim, trabalhar esse conceito nos remete à outra mentalidade jurídica voltada aos nossos interesses e nossas características históricas na América Latina. Repensar a justiça a partir da comunidade põe em crítica os modelos tradicionais de acesso à justiça.

O autor Edgar Ardila não só demonstra a importância da resolução dos conflitos por meio da normatividade social determinada pela comunidade, mas também afirma que, num processo de ruptura social, como é a situação de uma desavença individual ou uma indis- 
posição coletiva em termos comunitários, pode haver identidade e sentimento de pertença. O Estado olha a desavença como litígio, fator negativo ao que se deve "calcular" leis, multiplicar por súmulas e entendimentos jurisprudenciais e resultar numa sentença para sanar a problemática jurídica.

$\mathrm{Ou}$, ainda, quando muito, treinar sujeitos que serão agentes da justiça (tradicional) para operar, por meio do diálogo e da mediação, em suas próprias comunidades, levando em conta as regras do Estado. Novamente, de maneira alguma, atribuímos descrédito a essas práticas, mas, como a proposta é critica e reflexiva em busca de um resgate de identidade autônoma, emancipada num contexto de secular colonização, pautamos-nos nos projetos que contenham em seu âmago a marca indelével de um pluralismo jurídico com participação popular comunitária.

Nessa linha de identificação do que pugnamos por justiça comunitária, vamos trazer a definição do que seja comunidade:

Podemos definir la comunidad como un conjunto complejo de relaciones sociales basadas en un sentimiento común de pertenencia al mismo grupo. Ese sentimiento se expresa y materializa mediante la orientación de los comportamientos según las normas sociales que son comunes al mismo. Tal sentimiento puede ser ocasionado por afectos o tradición (...). Nos valemos de un concepto de comunidad como el conjunto que nos permita recoger las dinámicas actualmente existentes en la realidad social de nuestra época. ${ }^{32}$

Contudo, torna-se importante destacar que determinadas práticas não se coadunam com justiça comunitária, como, a título de exemplo, linchamentos, que são frequentemente identificados como justiça comunitária. Edgar Ardila alerta que "Los linchamientos son un fenómeno presente en distintos contextos sociales [...] Justicia comunitaria es normatividad y los linchamientos son lo contrario, porque, precisamente, omiten y violan las normas y las instituciones". ${ }^{33}$ No caso, mencionamos acima que justiça comunitária parte do pressuposto de que haja uma normatividade social, uma organização comunitária em um esquema de institucionalização por meio de lideranças num processo político de democracia participativa. 
Com essas afirmações, novamente vale mencionar, de forma expressiva e esclarecedora por Edgar Ardila, que não haverá justiça comunitária, se não houver comunidade, administração democrática da justiça e processos de identidade e pertença, logo,

Dicho de un modo simple: para que haya justicia comunitaria es necesario que haya administración de justicia y que haya comunidad. Si falta alguna de las dos, estaremos frente a otro tipo de situación. No será justicia comunitaria si se gestionan conflictos sin obligatoriedad derivada del ámbito social específico. No será justicia comunitaria si el ámbito social en el que se inscribe la gestión no considera dinámicas de identidad y pertenencia. ${ }^{34}$

O autor mencionado elabora três vetores de desenvolvimento de justiça comunitária, que estão intimamente ligados com o processo da "tríade" trabalhado na primeira parte. Em ambos ficam claros os objetivos a que se pretende chegar, bem como a ideia final de uma justiça comunitária voltada aos interesses da própria comunidade:

[...] proponemos tres grandes vectores en los procesos de desarrollo de la justicia en equidad en los ámbitos sociales: (1) como agentes del Estado, portadores de un discurso del derecho oficial, al cual se encuentran totalmente subordinados; (2) como oferentes de un servicio de gestión de conflictos, comprometidos en su calidad y en la satisfacción de una demanda sometidos a las normas del mercado y; (3) como miembros de una comunidad y parte de sus estructuras de autoridad, vinculados culturalmente al ámbito social cuyas reglas son reconocibles. ${ }^{35}$

Dessa maneira, as dinâmicas colocadas por membros da comunidade e sua normatividade social superam a tradicional dificuldade cultural calcada no acesso à justiça tradicional. ${ }^{36}$ Se há diferenças em relação às retóricas, normatividades abstratas, vestes, palavreados e a imponência silenciosa dos prédios e das autoridades estatais, apresenta-se a justiça produzida pelos próprios atores do bairro, feita em sua linguagem dentro do seu cotidiano e em seu território, naquilo que identificam como símbolo de sua união política: a associação de bairro ou sede da comunidade. Em razão disso, nossa crítica ao modelo tradicional de acesso à justiça e suas facetas estatais parte daquilo que dirá Dussel: 
Os excluídos não devem ser incluídos (seria como introduzir o Outro no Mesmo) no antigo sistema, mas devem participar como iguais em um novo momento institucional (a nova ordem política). Não se luta pela inclusão, mas sim pela transformação [...]. A democracia crítica, libertadora ou popular (porquanto povo é o ator principal), põe em questão o grau anterior de democratização alcançado; já que a democracia é um sistema a ser reinventado perenemente. ${ }^{37}$

Na mesma linha de entendimento político, pautamos nossa análise por dinâmicas na busca pela transformação e superação da crise do modelo de juridicidade moderna para um contexto diferenciado.

As propostas dos países andinos estão justificadas em seu contexto social de identificação e conscientização política pela luta, bem como pela necessidade de buscar a satisfação de seus direitos, numa proposta insurgente ao contexto histórico de colonização, submissão e opressão. Diante de tais afirmações, o ponto de diferenciação em relação aos modelos estatais, está "onde se produz", " por quem é produzida" e "como se produz justiça" e, ainda, com qual "finalidade tal produção jurídica". Enfim, sobre a busca pela própria transformação do espaço de administração da justiça de uma forma democrática, em que a conquista da paz pelo diálogo e os sentimentos de identidade e pertença sejam exaltados, Edgar Ardila nos apresenta que:

Hay una fuerte armonía cultural con los procedimientos y los criterios de decisión que enmarcan la labor del juez de paz: El juez de paz es parte de la comunidad, es la comunidad misma, interactúa con sus vecinos, y por eso, de acuerdo a la forma como se identifique con ellos y resuelva los conflictos, los vecinos acudirán a él Son los usos, las costumbres y las tradiciones locales los referentes con los que corrientemente administran justicia. ${ }^{38}$

Assim, torna-se importante, segundo o autor,

Desde esta perspectiva sustentaremos que los procesos de desarrollo comunitario no son sólo el terreno de la gestión pacífica y comunitaria de los conflictos sino de transformación de las propias dinámicas de regulación social y en esa medida, de desarrollo político de la comunidad y de democratización de la sociedad. ${ }^{39}$ 
Entendemos que uma das principais características da justiça comunitária andina, que é gerar identidade e pertença, é um importante caminho para resgatar uma história que foi sufocada, encoberta, ${ }^{40}$ dizimada. Em razão disso, a leitura é para a construção de uma nova cultura jurídica, plural, popular, comunitária e participativa, em que a refundação das instituições seja na base do poder popular, de protagonismo dos movimentos sociais, das coletividades oprimidas em um contexto latino-americano de luta, sobre o qual Edgar Ardila menciona,

Regiones enteras de América Latina han sido escenario de predominio del derecho estatal, implantado por los europeos en desmedro de los pueblos sometido. La juridicidad impuestas por élites descendientes del poder colonial rara vez ha dialogado con las estructuras culturales propias, ni con las tradicionales ni con las que han derivado de fuertes dinámicas, por tanto, cabe pensar que imponer formas rígidas a contextos sociales diferentes sólo puede ser a costa de sacrificar los universos de sentido intervenidos desde fuera de mestizaje entre las tres vertientes que nos constituyen: la amerindia, la afroamericana y la europea-criolla. Así, la juridicidad estatal en un amplio espectro de la vida social escasamente logra revestir con sus formalidades, prácticas sociales fuertemente arraigadas en las culturas indias y mestizas. ${ }^{41}$

Portanto, após a análise acima, passaremos a delinear as práticas de justiça comunitária em países como Colômbia e Peru, onde vamos constatar as características de identidade, pertença e fortes ralações comunitárias em busca da justiça e da produção da vida de forma igualitária em termos materiais.

\section{OS RONDEROS E OS COMUNEROS PERUANOS}

Em comunidades peruanas indígenas e/ou campesinas, surgem duas figuras que são legalmente reconhecidas pelo Estado, são os ronderos e os comuneros. Sujeitos que representam formas de organização para proteção comunitária e administração da justiça. Assim, as chamadas rondas campesinas são organizações de grupos para proteção das terras de uso comum contra roubos, furtos e outros tipos de violência, ao passo que os comuneros é uma designação que explica o sujeito participativo na vida da comunidade. A lei geral de comunidades campesinas (Ley $n^{\circ} 24656$, Art. $5^{\circ}$ ) establece que “[...] 
son comuneros los nacidos en la comunidad, los hijos de comuneros y las personas integradas a la comunidad". Essas figuras citadas na lei têm direito a fazer uso comum de bens e serviços.

Os chamados comuneros se dividem em algumas categorias que identificam sua participação e condição dentro das comunidades. Essas condições estão especificadas em estatuto comunitário "Los comuneros de las comunidades de Cusco y Puno conocen perfectamente cuáles son los requisitos para la condición de comunero, establecidas en los estatutos. Diferencian entre comuneros 'en calificación', comuneros 'calificados', comuneros 'no residentes' y comuneros 'descalificados" ${ }^{42}$ A principal vantagem de ser comunero é que, após solicitar a inscrição, se tem o acesso à terra e aos pastos, participação nas decisões das assembleias e, também, dar em contraprestação para a comunidade o trabalho comunal. Desse modo, qual a capacidade jurídica, os direitos e deveres dos comuneros e em que consiste essa comuna?

La organización de base principal es la Comuna, que constituye un conjunto de familias que viven en el territorio y se identifican como parte de un pueblo indígena. Son comuneros los residentes del lugar - sin diferenciación de género-, que son anotados en el 'Registro de habitantes de la comuna' o 'Registro de Cabildo'. Este libro es llevado por el presidente y el secretario del Cabildo (que es el órgano oficial de la comuna, integrado por cinco miembros). Los hijos de comuneros, cuando cumplen la mayoría de edad, tienen obligación de afiliarse. El beneficio es, que con la inscripción en el registro se convierten en sujetos de derechos de la comuna. A partir de este momento pueden demandar y tienen que cumplir con las obligaciones como las mingas. ${ }^{43}$

Diante das colocações, resta comprovado que as práticas comuneras visam à autonomia e emancipação das comunidades em termos de organização política e jurídica, com seus estatutos comunitários e consciência de prática solidária e comunal; ademais, resta destacar que as exigências para ser comuneros, somadas às demais qualificações, geram um sentido de identidade do grupo. O trabalho comunal feito em benefício da comunidade tem o sentido de pertença, ambos já destacados acima. Assim,

Se puede observar, que la organización comunal es fundamental para 
la identidad. El comunero se define como parte de la comunidad. Elementos constituyentes de la comunidad son 'la tierra', una visión cultural de trabajo que se expresa en la reciprocidad (hago algo por mi compañero, porque sé que él hará algo por mi) y en el trabajo comunitario. Su obligación es mantener la unidad, participar en las actividades y trabajos comunales y llevar a la comunidad hacia delante. Frente al mundo externo sólo la organización comunal tiene la capacidad de demandar y gestionar, de conseguir 'beneficios ${ }^{\prime 4}$.

Quanto aos ronderos campesinos, não há uma denominação exata dos tipos. Suas qualificações e classificações são confusas pelas denominações populares das comunidades, ao revés seus objetivos que são bem delineados e suas condutas comunais e direitos ${ }^{45}$ igualmente, "Los varones opinan que todos os habitantes de la localidad de la ronda campesina son ronderos (no mencionan una inscripción formal como requisito)" ${ }^{46}$

En cambio las mujeres afirman que sólo los varones son ronderos, porque las mujeres no realizan el 'servicio da ronda' desde las siete de la noche hasta las cinco de la mañana. Aunque se llaman 'ronderas' o integrantes de rondas femeninas, no se consideran propiamente como ronderas. Dicen que brindan sólo un apoyo a la ronda en algunas gestiones y en la resolución de conflictos, especialmente cuando los varones no pueden solucionar el problema. ${ }^{47}$

Entretanto, como em toda comunidade, existem figuras que se recusam a ingressar na lógica de vivência comunitária. Assim, os ronderos denominam "los morosos", pessoas que, após várias citações das autoridades ronderas, ignoram o chamado a cumprir as obrigações com o todo. Diante disso, os ronderos oferecem uma ferramenta de integração, chamada "La ley del hielo", que significa ignorar tais pessoas, formando uma espécie de pressão social para que elas tomem consciência de sua inserção na comunidade. Na realidade, consiste em aceitar o isolamento social de tais indivíduos. Ademais, '[...] los campesinos que no quieren formar parte de la ronda están expuestos a la desprotección: la ronda advierte a los rebeldes que ellos mismos tendrían que cuidar sus bienes y que no pueden contar con el apoyo de la ronda en un caso de daño o robo' ${ }^{48}$ 
Sendo assim, destacamos o que se convenciona como justiça para essas comunidades campesinas e indígenas, segundo discussões em oficinas realizadas pelos autores Brandt e Valdivia:

Justicia es percibido por las autoridades campesinas, en primer lugar, como proceso orientado a la resolución de un conflicto. El objetivo principal es superar el problema mediante la reflexión y el entendimiento de las partes y lograr una 'conciliación' o 'reconciliación'. [...] segundo, debe haber equidad e igualdad en el procedimiento; [...] tercero, el procedimiento debe ser gratuito, participativo, democrático y transparente; $[\ldots] .{ }^{49}$

Destacadas as peculiaridades das práticas de ronderos e comuneros no Peru, seguiremos pelas experiências de justiça comunitária voltando nossa atenção para a Colômbia e suas atividades de juízes de paz, justiça em equidade e justiça restaurativa.

\section{JUSTIÇA EM EQUIDADE E JUÍZES DE PAZ COLOM- BIANOS}

Iniciamos esta parte do trabalho destacando que talvez as propostas de juízes de paz e a justiça em equidade sejam as de justiça comunitária que mais dialogam e se aproximam de uma transformação da juridicidade tradicional em diálogo com o Estado. Assim, o viés em que esse diálogo acontece acaba confundindo as matrizes normativas e tem às vezes demasiada ingerência estatal nos núcleos e em suas atividades.

Porém, com essas ressalvas feitas, começaremos destacando os marcos legais que embasaram a desjudicialização, ou seja, o deslocamento da judicialidade do Estado para os núcleos comunitários. Na Colômbia, o movimento da Constituinte de 1991, no tocante à administração da justiça, pautou-se pela tarefa de descongestionar os aparatos judiciais do Estado abarrotados em demandas. Logo após, em 1996, surge a Lei n. ${ }^{\circ} 270$ que, em seu art. $8^{\circ}$, instaura o princípio da alternativade e possibilita o maior desenvolvimento da justiça comunitária. ${ }^{50}$

Assim, temos os conciliadores em equidade, figuras legalizadas com a Lei n. ${ }^{\circ} 23$, de 1991, conhecida como lei da descongestão judicial, embasada no art. 116 da Constituição colombiana, “[...] estando por tanto vinculada desde sus inicios como un mecanismo de economía 
procesal, y es que ésta constituye una institución procesal en la medida en que es una vía para solucionar un conflicto que ha surgido con ocasión de una relación de derecho, más no necesariamente de derecho legislado" ${ }^{51}$ A conciliação em equidade é desenvolvida na comunidade por líderes comunitários, os quais devem ter alguns requisitos preenchidos e com os seguintes objetivos:

Ser miembro activo al interior de la comunidad, con un oficio y domicilio reconocido; ser elegido y legitimado mediante nombramiento por un juez de la república, más la obtención de un certificado de aptitud suscrito por el Ministerio de Justicia y de Derecho; y por último, ejercer sus funciones de manera gratuita, y que promuevan dentro de sus respectivos sectores acuerdos conciliatorios que produzcan soluciones pacíficas, con un ingrediente peculiar, que la regulación del conflicto no se hace a través de la ley, sino que se recurre para ello a los valores, costumbres y conceptos de equidad y justicia imperantes en cada comunidad. ${ }^{52}$

Importa destacar que, apesar de advir de uma atividade de descongestão judicial estatal, esse modelo se propõe a resolver questões locais, por pessoas da própria comunidade que tenham interesses pela harmonia social. O conciliador ainda deve passar por treinamento nas instituições do Estado, mas pode, em sua atuação, utilizar a normatividade social para solucionar e legitimar seu trabalho.

Diante disso, vale mencionar que se compreende por conciliação e equidade, no âmbito da justiça comunitária, "La conciliación. El modelo conciliatorio, que busca la mutua satisfacción de las partes es el fundamento de las actuaciones, contrario a la justicia estatal en la que el modelo adjudicatorio busca la determinación de un vencedor",; 53 e por equidade "La equidad. La solución de un conflicto está más dirigida a la recomposición de la vida comunitaria que a la aplicación de una ley, por tanto lo que prima es que las decisiones se sometan a una concepción de justicia aceptable en cada contexto comunitario" ${ }^{54}$

Apesar de a idéia contar com forte influência do Estado na formação dos agentes, nada obsta reconhecer que seus objetivos sejam centros produtores de autonomia, participação e solidariedade. O advogado, professor universitário e integrante da "Red de Justicia Comunitaria", da localidade de Santander, na Colômbia, Rosembert 
Ariza Santamaría, demonstra-nos quais são os reais objetivos do conciliador, pelo olhar da comunidade,

El conciliador en equidad representa el interés de la comunidad en el conflicto, por lo que no es completamente ajeno al mismo, aspecto que no riñe con la imparcialidad que debe asumir, pues su interés no es concreto sino general, debido al cual, no sólo debe limitarse a buscar un acuerdo entre las partes, sino debe promover soluciones que beneficien la convivencia y abran caminos de desarrollo en la comunidad. ${ }^{55}$

Os juízes de paz surgem no mesmo contexto de reformas na administração da justiça colombiana com a Constituição de $1991 .^{56}$ Tais figuras estão mais próximas da lógica estatal devido aos instrumentos com os quais operam no contexto comunitário. E também da proximidade de sua atuação que é semelhante à do juiz togado, na medida em que pode emitir decisão sobre o caso concreto, "sentenças do juiz de paz", que tem reconhecimento pelo Estado no mesmo valor que uma decisão dos juízes de um tribunal estatal constituído, valendo, inclusive, como coisa julgada. ${ }^{57}$

Dessa forma, o juiz de paz se convenciona em um "braço" ou prolongamento do Estado instrumentalizado em meio alternativo de resolução de conflitos, utilizando-se dos mesmos aparatos de elegibilidade dos conciliadores na medida em que também recebe treinamento e é submetido a eleições populares, fazendo uso das normatividades sociais, só que com diferencial dos conciliadores que é a ingerência em certo grau de coercibilidade autorizado pelo Estado, ao passo que os conciliadores em equidade não disponibilizam de tal aparato,

La diferencia central radica en que los Jueces de Paz disponen de un mayor nivel de coercibilidad derivada del aparato estatal. Pueden valerse de una velocidad más en su caja de cambios. Mientras que el conciliador no está facultado por la ley para hacer comparecer a las partes o imponer una decisión a alguna de ellas, el juez de paz tal vez sí. Con ello se le da una herramienta de eficiencia como operador de justicia que, por lo dicho, sólo será aplicada en condiciones excepcionales. ${ }^{58}$

Entretanto, nada obsta mencionar que os conciliadores não ficam despossuídos de alguma formalidade ou ritualística em suas 
reuniões conciliatórias. Existe uma ata de acordo entre os envolvidos, porém, como a ideia é mais ampla, esta acaba nem sempre sendo uma obrigatoriedade. Como menciona Edgar Ardila, o objetivo é uma solução pacífica e de interesse geral da comunidade e não mera redação de uma ata. Seu desempenho consiste em algo como uma liderança de promoção da conscientização comunitária para o espaço de paz e harmonia. Assim,

Muchas actuaciones del conciliador, la mayoría en muchas comunidades, llegarán a una solución pero no a un acta. El papel do conciliador es prolongado en el tiempo y no se puede reducir a un momento procesal como una audiencia. Por el contrario, el conciliador tiene que ser visto como alguien que acompaña a las partes en un camino de búsqueda de una solución satisfactoria para ellas y justa en el contexto comunitario específico en el que se está actuando. ${ }^{59}$

Acrescentamos, ainda, que ambas as figuras representam novos paradigmas de acesso à justiça, no âmbito de administração, da mesma forma com fulcro comunitário, participativo, sob a égide de uma democracia de participação, seja na escolha dos juízes, conciliadores, ou até mesmo na participação em reuniões dos núcleos de justiça comunitária. Tais projetos, reconhecidos e apoiados pelo Estado, são o espaço que se abre para discussão do acesso à justiça para além da juridicidade formalizada e burocratizada pelas instituições do direito tradicional. Seguimos abaixo explorando uma forma de justiça alternativa que, assim como as experiências acima, se propõe à valorização dos sentimentos, cultura e história comunitária como normatividade na resolução dos conflitos e recomposição dos laços comunitários de paz e harmonia.

\section{JUSTIÇA RESTAURATIVA E RECOMPOSIÇÃO SOCIAL}

Neste ponto, a abordagem se centra na justiça restaurativa, mas necessário se faz um apontamento primordial, no sentido de basilar a concepção de justiça restaurativa adotada para o presente trabalho.

Assim, trabalha-se com a concepção de justiça restaurativa no sentido atribuído em sociedades denominadas de primitivas, tanto 
no Oriente quanto no Ocidente, entretanto, sempre vinculando a uma ideia de justiça comunitária.

Isso quer dizer que esse paradigma de justiça restaurativa possui elementos essenciais já apontados acima, como a sua íntima vinculação com a comunidade em que está inserida, desinstitucionalização e principalmente desjudicialização.

Nesse sentido, esclarece Milène Jaccoud:

Em virtude de seu modelo de organização social, as sociedades comunais (sociedades pré-estatais européias e as coletividades nativas) privilegiavam as práticas de regulamento social centradas na manutenção da coesão do grupo. Nestas sociedades, onde os interesses coletivos superavam os interesses individuais, a transgressão de uma norma causava reações orientadas para o restabelecimento do equilíbrio rompido e para a busca de uma solução rápida para o problema. Embora as formas punitivas (vingança ou morte) não tenham sido excluídas, as sociedades comunais tinham a tendência de aplicar alguns mecanismos capazes de conter toda a desestabilização do grupo social. ${ }^{60}$

Diferentemente do sentido atribuído à justiça restaurativa que tem preponderado no Brasil e que, ainda que possua alguns elementos progressistas em relação à justiça retributiva e ordinária, mantém as amarras inerentes ao Poder Público estatal e o seu Poder Judiciário com as suas respostas prontas e gerais, abstratas e seu código de normas universais.

É interessante fazer uma breve análise, observando que ao paradigma que se denomina de epistemologia ocidental se atribui a capacidade de ter produzido toda a grande carga racional de seu mundo ocidental e que, com essa carga racionalista e seu mapa cognitivo, foi colonizando e dominando os povos bárbaros, indígenas, desconhecidos, não socializados. Entretanto, verifica-se que esse paradigma de justiça precária, simplista e monista faz parte deste mapa cognitivo moderno-ocidental incompreensivo. O paradigma alternativo de justiça parte justamente das bases aniquiladas por esse processo colonizador aniquilador de culturas e práticas, dentre as quais se incluem as restaurativas e comunitárias, que eram largamente utilizadas em povos indígenas, grupos tidos como bárbaros ou naturais. ${ }^{61} \mathrm{Ou}$ seja, as capacidades modernas ocidentais permitiram aos indivíduos domi- 
nar a natureza e a tudo a que se atribui essa naturalidade passível de dominação e domesticação. ${ }^{62}$

Assim, tendo-se delimitado a concepção de justiça restaurativa a partir de uma ideia de justiça comunitária, passa-se, então, à análise e justificação dessa dinâmica ético-dialogal da alteridade de empoderamento verdadeira e substancialmente cidadã.

Nesse sentido, inicia-se esta abordagem com uma colocação questionadora/ propositiva de Afonso Konzen:

Por quê? O que fazer? A massa dos encarcerados, a (des)organização produzida a partir da falência do Estado-aprisionador, a incapacidade resolutiva das políticas de segurança, os reclamos por mais e mais investimentos em repressão, a insuficiência das políticas sociais, as explicações para o fenômeno, tudo leva ao desespero pela retórica esvaziada dos discursos sem efetiva repercussão no campo das soluções. Não se estaria depositando expectativas demasiadas na real capacidade de responder dos sistemas estatais encarregados de responder? Não seria demasiada a expectativa na eficácia das respostas de natureza penal? Não estaria em crise a crença na resolução da violência pelo uso de respostas também violentas? Não estaria em crise a própria condição humana, pela forma como o homem, notadamente a partir da modernidade, passou a sentir-se proprietário absoluto da natureza e do outro ser humano, tudo a seu servir, fonte inesgotável de exploração, tudo para o acumular e para o prazer? ${ }^{63}$

Em um esforço de tentar subsidiar algumas respostas às indagações de Konzen, ${ }^{64}$ ou simplesmente reforçando a necessidade de reflexão sobre tais questões, encontra-se a importância da justiça restaurativa.

Assim, o primeiro bloco de questões formuladas por Konzen se dirige e se pode dizer que são o grande objetivo da justiça restaurativa. Já no que diz respeito ao segundo bloco, verifica-se que as respostas servem, ao mesmo tempo, para a legitimação da justiça restaurativa, dado que também se mostram como um atestado de ineficácia do paradigma punitivista propugnado pela justiça ordinária.

Nesse sentido, a partir de uma justiça restaurativa comunitária, a resolução de conflitos se pautaria por algumas questões que simplesmen- 
te passam despercebidas pelo Poder Estatal, ou sequer fazem parte de sua concepção de conflito. Questões como: possibilitar e instigar o diálogo entre os envolvidos, inclusive rompendo com a dinâmica de atribuir papéis de agressor e agredido, para que, com esse diálogo, se viabilize a reconstrução do laço rompido pelo conflito. Ademais, possibilita-se, com esse diálogo, que cada indivíduo tome conhecimento das razoes do outro e do impacto sofrido com o conflito e suas causas, o que proporciona uma retomada da ideia de uma relação que preconiza a solidariedade pelos sofrimentos, razões e consequências, que são mútuas.

Acrescente-se, ainda, a importância de representantes da sociedade em meio a esse diálogo. Pessoas ligadas a cada uma das partes, tendo em vista que os conflitos não atingem somente os diretamente envolvidos, mas também ao indivíduos a eles próximos, que podem e devem trazer seus discursos e contribuir com esse processo restaurativo comunitário e alternativo.

Por fim, um representante da comunidade, como um todo autônomo, ainda que heterogêneo, mas representando os interesses da comunidade, como uma terceira figura, e que longe está de ser neutra, mas que pretenda, sim, reatar esse conflito, uma vez que a comunidade também é afetada e agredida pelo conflito. Dessa feita, é em proveito também da comunidade a restauração desse laço comunitário e de solidariedade.

Saliente-se que a justiça comunitária, como se pode claramente perceber, propugna por um processo alternativo, sem qualquer regra ou receita predefinida, e se desenvolve de acordo com o avanço dos diálogos, dos discursos e pretensões apresentados e suas necessidades. Assim, preocupa-se com o futuro da comunidade e das relações que a envolvem, e não em reconstituir o status quo ante ou produzir uma verdade artificial, como pretende a processualidade ordinária estatal, com vistas a culpar um ou (re)vitimizar o outro - ou ainda ambos ao mesmo tempo e independente da decisão final.

Nessa linha, vale a colocação de Marcos Rolim:

É muito difícil compreender que o paradigma que consideramos tão natural, tão lógico, tem, de fato, governado nosso entendimento sobre o crime e justiça por apenas alguns poucos séculos. Nós não fizemos sempre da mesma forma e, ao invés desse modelo, as práticas de Justiça 
Comunitária acompanharam a maior parte de nossa história. Por todo esse tempo, técnicas não-judiciais e formas não-legais de resolução de conflitos foram amplamente empregadas. As pessoas, tradicionalmente, eram muito relutantes em apelar para o Estado, mesmo quando o Estado pretendia intervir. De fato, quem apelasse ao Estado para a persecução penal poderia ser estigmatizado por isso. Por séculos, a intervenção do Estado na área de persecução criminal foi mínima. Ato contínuo, era considerado um dever das comunidades resolver suas próprias disputas internas. ${ }^{65}$

Nessa esteira, trabalhando a procedimentalidade adotada por um paradigma de justiça restaurativa e comunitária, é necessário trazer um elemento fulcral a essa dinâmica dialogal e que se pauta não pelo direito legislado, mas por topos ou topoi, ou seja, um corpo de valores que sejam comuns e comunitariamente aceitos e que permita aos indivíduos transitarem em seus discursos, saberes e necessidades de recomposição, não ficando atrelados a uma receita ou procedimentalidade determinada hegemônica e legitimada pela sua oficialidade, como bem propõe Boaventura de Sousa Santos:

Esta falta de uniformidad, que puede sorprender lo mismo que escandalizar a quien vea con los ojos etnocéntricos del derecho oficial, no es, sin embargo, caótica. Es determinada por las exigencias normativas y de seguridad, que se van definiendo a lo largo del proceso de prevención o resolución de los conflictos. En Pasárgada, las formas y los requisitos procesales mantienen un estricto carácter instrumental y como tal son usados sólo en la medida en que pueden contribuir para una decisión justa de la causa [...] se desarrolla así, a partir del formalismo elaborado del sistema jurídico estatal, un formalismo popular. ${ }^{66}$

Assim, a título ilustrativo, permite-se trazer o topoi de ubuntu que serve de elemento-guia para a justiça comunitária em povos africanos, utilizando novamente a contribuição de Rolim. ${ }^{67}$

É por essas razões que se preconiza um paradigma de juridicidade alternativa, verdadeiramente democrático e que possibilite a representação comunitária e manutenção dos interesses dessa comunidade em que os conflitos se inserem, assim como também reapropriar os envolvidos e seus contextos na resolução dos próprios conflitos, de forma dialogal e a partir de relações horizontalizadas. 
Dessa feita, entende-se e procura-se teorizar a justiça restaurativa comunitária como sendo o percurso que possa a dar conta das complexidades relacionais modernas, bem como, ainda, possibilite um rompimento com esse paradigma de justiça eurocêntrico, calcado em relações hierarquizadas e que invisibilizam as dores em prol de uma fictícia verdade real, que apenas produz legitimação para um Estado Dominador por meio de seu Judiciário Opressivo.

\section{CONSIDERAÇÕES FINAIS}

Intentamos, neste deste estudo, refletir sobre o acesso à justiça a partir dos marcos de uma juridicidade em crise, que hegemoniza, ritualiza e se distancia da sociedade. Assim, problematizamos o monismo estatal e a mitologia jurídica moderna, reconhecendo a existência de um contexto de pluralismo jurídico: estatal e comunitário, num sentido de se pautar por um específico modelo teórico denominado pluralismo jurídico comunitário participativo, exposto no trabalho nas experiências de justiça comunitária andina.

Nesse sentido, tal reflexão marca as linhas de um rompimento na cultura jurídica monista latino-americana, por meio da democratização da justiça pela descentralização da sua administração, num espaço geopolítico historicamente de isolamento das camadas populares pelas instituições estatais. Espaço negado, onde essas camadas podem insurgir-se, tendo a oportunidade de impor suas demandas num processo político participativo, ao qual, por meio de suas práticas de juridicidade alternativa, irrompe uma nova cultura jurídica, em que o diálogo intercultural, a identidade e a comunidade são suas principais características.

Contudo, não ignoramos o contexto de hegemonia estatal envolvido e/ou comprometido política, econômica e juridicamente com as relações de mercado, em que os sujeitos estão reduzidos às suas condições vulneráveis nas relações consumeristas. Ao apresentarmos as experiências de justiças comunitárias andinas, pautamos-nos por uma leitura histórica do contexto de dominação cultural eurocêntrica, na qual as características de gerar identidade e pertença problematizam as instituições modernas e suas relações na sociedade globalizada. 
Ao apresentarmos essas experiências, destacamos o diálogo com a normatividade estatal pelas ingerências comunitárias e sua normatividade social, demonstrando que, além de resolver conflitos, as demandas sociais devem ser pautadas pela identificação social e um sentimento de reatar os laços de sociabilidade. Para isso, faz-se necessária a atuação de sujeitos envolvidos na própria cotidianidade da comunidade.

Ao trabalharmos o programa reformista do Estado, nossa proposta visa, além de exigir a ingerência participativa dos novos sujeitos sociais, a propugnar pela transformação de um contexto político em crise, de uma modernidade esgotada epistemologicamente, em que seus mitos jurídicos não se sustentam na realidade complexa e diversificada. Pelo exposto de forma crítico-reflexiva e por essas temáticas e elementos, reafirmamos as bases teóricas a as atividades práticas para uma práxis cotidiana de refundação e contra-hegemonia política e jurídica na América Latina.

\section{NOTAS}

1 SANTOS, Boaventura de Sousa (Org.). Democratizar a democracia: os caminhos da democracia participativa. Rio de Janeiro: Civilização Brasileira, 2005.

2 WOLKMER, Antonio Carlos. Pluralismo jurídico: fundamentos de uma nova cultura do direito. 3. ed. São Paulo: Editora Alfa Omega, 2001. p. 70

3 GROSSI, Paolo. Mitologias jurídicas da modernidade. Tradução de Arno Dal Ri Júnior. Florianópolis: Fundação Boiteux, 2004.

4 SANTOS, Boaventura de Sousa. Para uma revolução democrática da justiça. São Paulo: Cortez, 2007. p. 22.

5 SANTOS, Boaventura de Sousa. Para uma revolução democrática da justiça. São Paulo: Cortez, 2007.

6 SANTOS, Boaventura de Sousa. Para uma revolução democrática da justiça. São Paulo: Cortez, 2007. p. 31

7 GROSSI, Paolo. Mitologias jurídicas da modernidade. Tradução de Arno Dal Ri Júnior. Florianópolis: Fundação Boiteux, 2004.

8 SANTOS, Boaventura de Sousa. Para uma revolução democrática da justiça. São Paulo: Cortez, 2007. p. 32

9 CAPPELLETTI, Mauro; GARTH, Bryant. Acesso à justiça. Porto Alegre: Editora Fabris, 1988.

10 SANTOS, Boaventura de Sousa. Para uma revolução democrática da justiça. São Paulo: Cortez, 2007. p. 76

11 WOLKMER, Antonio Carlos. Sociedad civil, poder comunitario y acceso democrático a la justicia. Revista El Otro Derecho, ILSA, Bogotá, Colombia, n. 26 , p. 139, abr. 2002.

12 "Os corpos intermediários devem ser entendidos como grupos sociais ou voluntários com interesses comuns, localizados entre o Estado e o indivíduo, com atribuições para representar diferentes setores da comunidade e atuar num espaço democrático, caracterizado pela descentralização e participação popular" (WOLKMER, 2001, p. 120).

13 Para Wolkmer: "Derecho insurgente es un derecho paralelo, vivo y comunitario que emerge permanentemente de los intereses y las necesidades de la sociedad. Es a creación y el re- 
conocimiento de derechos fundamentales [derecho a la vida, a libertad, a la sobrevivencia, etc.], distinto de las normas positivas oficiales, engendradas en los conflictos y en luchas de grupos sociales, pudiendo coexistir o oponerse a las leyes elaboradas por la actividad estatal [...]" (2002, p. 145)

14 MASCARO, Alysson Leandro. Filosofia do direito. São Paulo: Editora Atlas, 2010. p. 299

15 BAUMAN, Zygmunt. Modernidade líquida. Rio de Janeiro: Jorge Zahar Editor, 2001.

16 MIGNOLO, Walter. Os esplendores e as misérias da ciência: colonialidade, geopolítica do conhecimento e pluri-versalidade epistêmica, 2006. p. 668

17 SANTOS, Boaventura de Sousa. Refundación del Estado en América Latina: perspectivas desde una epistemología del Sur. Lima/ Perú: Red Latinoamericana de Antropología Jurídica, 2010. p.123.

18 WOLKMER, Antonio Carlos. Pluralismo jurídico: fundamentos de uma nova cultura do direito. 3. ed. São Paulo: Editora Alfa Omega, 2001.

19 WOLKMER, Antonio Carlos. Pluralismo jurídico: fundamentos de uma nova cultura do direito. 3. ed. São Paulo: Editora Alfa Omega, 2001. p. 63

20 SANTOS, Boaventura de Sousa. Democratizar a democracia: os caminhos da democracia participativa. 3. ed. Rio de Janeiro: Civilização Brasileira, 2005.

21 WOLKMER, Antonio Carlos. Pluralismo jurídico: fundamentos de uma nova cultura do direito. 3. ed. São Paulo: Editora Alfa Omega, 2001.

22 WOLKMER, Antonio Carlos. Pluralismo jurídico: fundamentos de uma nova cultura do direito. 3. ed. São Paulo: Editora Alfa Omega, 2001. p. 78

23 YRIGOYEN FAJARDO, apud WOLKMER, Antonio Carlos. Pluralismo jurídico: os novos caminhos da contemporaneidade. São Paulo: Editora Saraiva, 2010. p. 47

24 "Entendemos por administración de justicia un conjunto de instituciones, procedimientos y actores a los que corresponde regular los comportamientos legítimos que han de tener tanto los sujetos implicados como su entorno inmediato, dada una situación de conflicto. La administración de justicia establece y precisa las normas de comportamiento que son necesarias para que al regular una situación de conflicto, el orden social continúe garantizando la convivencia" (ARDILA AMAYA, 2006, p. 78).

25 CAMPILONGO, apud WOLKMER, Antonio Carlos. Pluralismo jurídico: fundamentos de uma nova cultura do direito. 3. ed. São Paulo: Editora Alfa Omega, 2001. p. 77

26 "La participación progresista del operador en equidad deriva de que éste propicie el diálogo entre dos versiones disímiles del conflicto y las normas que lo enmarcan y no de que imponga la versión de justicia que acoge. El operador de justicia ha de promover que las culturas conozcan que sus modos de resolver los conflictos provienen de concepciones diferentes de la realidad, ya que las diferencias no impiden llegar a un consenso internormativo. Presumir lo contrario, esto es, que dos culturas no pueden comunicarse y lograr consensos, implica asumir posiciones absolutistas que sólo llevan a la descalificación y exclusión del otro antes de ser escuchado" (ARDILA AMAYA, 2006, p. 128).

27 ARDILA AMAYA. Justicia comunitaria y sociedad nacional. Revista Cuarto Intermedio, Cochabamba, Bolívia: Es una revista trimestral de la Compañía de Jesús en Bolivia, p. 80-104, abr. 2010.

28 ARDILA AMAYA. Elementos para el debate de la figura de los Jueces de Paz. In: LÓPEZ B., Manuel et al. Justicia comunitaria y jueces de paz: las técnicas de la paciencia. Medellín, Colombia: Corporación Región; Red de Justicia Comunitaria, Instituto Popular de Capacitación de la Corporación de Promoción Popular, 2000. p.73

29 CHIVI VARGAS, Idón Moisés. Hacia la descolonización de la justicia. Revista Cuarto Intermedio. Cochabamba, Bolivia: Es una revista trimestral de la Compañía de Jesús en Bolivia, p.93-94, abr. 2010. -Tradução livre dos autores.

30 CHIVI VARGAS, Idón Moisés. Hacia La descolonización de la justicia. Revista Cuarto Intermedio, Cochabamba, Bolivia: Es una revista trimestral de la Compañía de Jesús en Bolivia, p. 93-94, abr. 2010.

31 ARDILA AMAYA. Justicia comunitaria y sociedad nacional. Revista Cuarto Intermedio, Cochabamba, Bolívia: Es una revista trimestral de la Compañía de Jesús en Bolivia, p. 80-104, abr. 2010 
32 ARDILA AMAYA, Edgar. A dónde va la justicia comunitaria en Colombia? Medellín: Corporación Región, 2006. p. 92

33 ARDILA AMAYA. Justicia comunitaria y sociedad nacional. Revista Cuarto Intermedio, Cochabamba, Bolívia: Es una revista trimestral de la Compañía de Jesús en Bolivia, p. 80-104, abr. 2010.

34 ARDILA AMAYA. Justicia comunitaria y sociedad nacional. Revista Cuarto Intermedio Cochabamba, Bolívia: Es una revista trimestral de la Compañía de Jesús en Bolivia, p. 80-104, abr. 2010.

35 ARDILA AMAYA. Justicia comunitaria y sociedad nacional. Revista Cuarto Intermedio Cochabamba, Bolívia: Es una revista trimestral de la Compañía de Jesús en Bolivia, p. 80-104, abr. 2010.

36 CAPPELLETTI, Mauro. GARTH, Bryant. Acesso à justiça. Porto Alegre: Editora Fabris, 1988

37 DUSSEL, Enrique. 20 teses de política. Buenos Aires: Consejo Latinoamericano de Ciencias Sociales - CLACSO; São Paulo: Expressão Popular, 2007. p. 111

38 GUERRA, apud ARDILA AMAYA, Edgar (Coord.). A dónde va la justicia comunitaria en Colombia? Medellín: Corporación Región, 2006. p. 146

39 ARDILA AMAYA, Edgar (Coord.). A dónde va la justicia comunitaria en Colombia? Medellín: Corporación Región, 2006. p. 149

40 DUSSEL, Enrique. El encubrimiento del otro, hacia el origen del "mito de la modernidad". Colección Academia, no. Uno. Plural editores - Facultad de Humanidades y Ciencias de la Educación - UMSA, La Paz, 1994.

41 ARDILA AMAYA, Edgar. Justicia comunitaria y sociedad nacional. Revista Cuarto Intermedio, Cochabamba, Bolívia: Es una revista trimestral de la Compañía de Jesús en Bolivia, p. 80-104, abr. 2010.

42 BRANDT, Hans-Jürgen; FRANCO VALDIVIA, Rocío. Justicia en los Andes: Perú y Ecuador. Normas, valores y procedimientos en la justicia comunitaria: estudio cualitativo en comunidades indígenas y campesinas de Ecuador y Perú, Instituto de Defensa Legal - IDL, Lima, 2007. v. 2, p. 51

43 BRANDT, Hans-Jürgen; FRANCO VALDIVIA, Rocío. Justicia en los Andes: Perú y Ecuador. Normas, valores y procedimientos en la justicia comunitaria: estudio cualitativo en comunidades indígenas y campesinas de Ecuador y Perú, Instituto de Defensa Legal - IDL, Lima, 2007. v. 2, p. 55.

44 BRANDT, Hans-Jürgen; FRANCO VALDIVIA, Rocío. Justicia en los Andes: Perú y Ecuador. Normas, valores y procedimientos en la justicia comunitaria: estudio cualitativo en comunidades indígenas y campesinas de Ecuador y Perú, Instituto de Defensa Legal - IDL, Lima, 2007. v. 2, p. 56.

$45 \mathrm{El}$ art. 7 del Estatuto de Rondas Campesinas y Urbanas-Cutervo, provincia de Cutervo, Región Cajamarca establece lo siguiente: “[...] los derechos de todo rondero son: tener voz y voto en las Asambleas Generales. Elegir y ser elegido a cualquier cargo o comisión de trabajo" (BRANDT; VALDIVIA, 2007, p. 53)

46 BRANDT, Hans-Jürgen; FRANCO VALDIVIA, Rocío. Justicia en los Andes: Perú y Ecuador. Normas, valores y procedimientos en la justicia comunitaria: estudio cualitativo en comunidades indígenas y campesinas de Ecuador y Perú, Instituto de Defensa Legal - IDL, Lima, 2007. v. 2, p. 54

47 BRANDT, Hans-Jürgen; FRANCO VALDIVIA, Rocío. Justicia en los Andes: Perú y Ecuador Normas, valores y procedimientos en la justicia comunitaria: estudio cualitativo en comunidades indígenas y campesinas de Ecuador y Perú, Instituto de Defensa Legal - IDL, Lima, 2007. v. 2, p. 54

48 BRANDT, Hans-Jürgen; FRANCOVALDIVIA, Rocío. Justicia en los Andes: Perú y Ecuador. Normas, valores y procedimientos en la justicia comunitaria: estudio cualitativo en comunidades indígenas y campesinas de Ecuador y Perú, Instituto de Defensa Legal - IDL, Lima, 2007. v. 2, p. 54

49 BRANDT, Hans-Jürgen; FRANCO VALDIVIA, Rocío. Justicia en los Andes: Perú y Ecuador. Normas, valores y procedimientos en la justicia comunitaria: estudio cualitativo en comunidades indígenas y campesinas de Ecuador y Perú, Instituto de Defensa Legal - IDL, Lima, 2007. v. 2, p. 54 
50 SANTAMARÍA, Rosembert Ariza. La justicia comunitaria: aportes a la construcción de un nuevo orden jurídico social. In: LÓPEZ B. Manuel et al. Justicia comunitaria y jueces de paz: las técnicas de la paciencia. Medellín, Colombia: Corporación Región; Red de Justicia Comunitaria, Instituto Popular de Capacitación de la Corporación de Promoción Popular, 2000.

51 SANTAMARÍA, Rosembert Ariza. La justicia comunitaria: aportes a la construcción de un nuevo orden jurídico social. In: LÓPEZ B. Manuel et al. Justicia comunitaria y jueces de paz: las técnicas de la paciencia. Medellín, Colombia: Corporación Región; Red de Justicia Comunitaria, Instituto Popular de Capacitación de la Corporación de Promoción Popular, 2000. p. 53

52 SANTAMARÍA, Rosembert Ariza. La justicia comunitaria: aportes a la construcción de un nuevo orden jurídico social. In: LÓPEZ B. Manuel et al. Justicia comunitaria y jueces de paz: las técnicas de la paciencia. Medellín, Colombia: Corporación Región; Red de Justicia Comunitaria, Instituto Popular de Capacitación de la Corporación de Promoción Popular, 2000. p. 55.

53 ARDILA AMAYA. Elementos para el debate de la figura de los Jueces de Paz. In: LÓPEZ B. Manuel et al. Justicia comunitaria y jueces de paz: las técnicas de la paciencia. Medellín, Colombia: Corporación Región; Red de Justicia Comunitaria, Instituto Popular de Capacitación de la Corporación de Promoción Popular, 2000. p. 74

54 ARDILA AMAYA. Elementos para el debate de la figura de los Jueces de Paz. In: LÓPEZ B. Manuel et al. Justicia comunitaria y jueces de paz: las técnicas de la paciencia. Medellín, Colombia: Corporación Región; Red de Justicia Comunitaria, Instituto Popular de Capacitación de la Corporación de Promoción Popular, 2000. p. 75

55 SANTAMARÍA, Rosembert Ariza. La justicia comunitaria: aportes a la construcción de un nuevo orden jurídico social. In: LÓPEZ B. Manuel et al. Justicia comunitaria y jueces de paz: las técnicas de la paciencia. Medellín, Colombia: Corporación Región; Red de Justicia Comunitaria, Instituto Popular de Capacitación de la Corporación de Promoción Popular, 2000. p. 56.

56 La Constitución Nacional de 1991, creo la figura de los Jueces da Paz como una jurisdicción especial, en el articulo 247 - “La ley podrá crear jueces de paz encargados de resolver en equidad conflictos individuales y comunitarios. También podrá ordenar que se elijan por votación popular", y luego de ocho años y medio de expedida la carta, es aprobada por el congreso de la república la ley 497 del 10 de febrero de 1999, "Por la cual se crean los jueces de paz y se reglamenta su organización y funcionamiento [...]” (SANÍN VÁSQUEZ, 2000, p. 143).

57 ARDILA AMAYA. Elementos para el debate de la figura de los Jueces de Paz. In: LÓPEZ B. Manuel et al. Justicia comunitaria y jueces de paz: las técnicas de la paciencia. Medellín, Colombia: Corporación Región; Red de Justicia Comunitaria, Instituto Popular de Capacitación de la Corporación de Promoción Popular, 2000.

58 ARDILA AMAYA. Elementos para el debate de la figura de los Jueces de Paz. In: LÓPEZ B. Manuel et al. Justicia comunitaria y jueces de paz: las técnicas de la paciencia. Medellín, Colombia: Corporación Región; Red de Justicia Comunitaria, Instituto Popular de Capacitación de la Corporación de Promoción Popular, 2000. p. 83

59 ARDILA AMAYA. Elementos para el debate de la figura de los Jueces de Paz. In: LÓPEZ B. Manuel et al. Justicia comunitaria y jueces de paz: las técnicas de la paciencia. Medellín, Colombia: Corporación Región; Red de Justicia Comunitaria, Instituto Popular de Capacitación de la Corporación de Promoción Popular, 2000. p.79

60 JACCOUD, Mylène. Princípios, tendências e procedimentos que cercam a justiça restaurativa. In: SLAKMON, Catherine; VITTO, Renato Campos Pinto de; PINTO, Renato Sócrates Gomes (Org.). Justiça Restaurativa. Brasília: Ministério da Justiça e Programa das Nações Unidas para o Desenvolvimento, 2005. p. 163.

61 ROLIM, Marcos. Justiça restaurativa: para além da punição. Disponível em: <www.comunidadesegura.org/files/active/0/Marcos_Rolim_Justica_Restaurativa.pdf.> . Acesso em: 26 abr. 2011.

62 SANTOS, Boaventura de Sousa. Um discurso sobre as ciências. Porto: Edições Afrontamento, 1987. 
63 KONZEN, Afonso Armando. Justiça restaurativa e ato infracional: desvelando sentidos no itinerário da Alteridade. Porto Alegre: Livraria do Advogado Editora, 2007. p. 103.

64 KONZEN, Afonso Armando. Justiça restaurativa e ato infracional: desvelando sentidos no itinerário da Alteridade. Porto Alegre: Livraria do Advogado Editora, 2007.

65 ZEHR apud ROLIM, Marcos. Justiça restaurativa: para além da punição. Disponível em: <www.comunidadesegura.org/files/active/0/Marcos_Rolim_Justica_Restaurativa.pdf.>. Acesso em: 26 abr. 2011

66 SANTOS, Boaventura de Sousa. Para uma revolução democrática da justiça. São Paulo: Cortez, 2007. p. 220-221.

67 "O entendimento africano tradicional de Ubuntu afirma o vínculo orgânico da humanidade, um vínculo realizado dentro e através das outras pessoas. A noção está presente no provérbio Xhosa: umuntu ngumuntu ngabantu', o que poderia ser traduzido como: 'uma pessoa é uma pessoa através das outras pessoas'. Ubuntu é comumente descrito através da seguinte fala: 'eu sou porque você é' ou 'minha humanidade está vinculada com sua humanidade" (VILLA-VICENCIO, apud ROLIM, Marcos. Justiça restaurativa: para além da punição). Disponível em: <www.comunidadesegura.org/files/active/0/Marcos_Rolim_Justica_Restaurativa. pdf.)>. Acesso em: Acesso em: 26 abr. 2011.

\section{REFERÊNCIAS}

ARDILA AMAYA, Edgar (Coord.). A dónde va la justicia comunitaria en Colombia? Medellín: Corporación Región, 2006.

. Justicia comunitaria como realidad contemporánea: claves para el estudio de las políticas en justicia comunitaria. Revista El Otro Derecho, ILSA: Bogotá, Colombia, n. 30, dez. 2003.

Elementos para el debate de la figura de los Jueces de Paz.

In: LÓPEZ B. Manuel et al. Justicia comunitaria y jueces de paz: las técnicas de la paciencia. Medellín, Colombia: Corporación Región; Red de Justicia Comunitaria, Instituto Popular de Capacitación de la Corporación de Promoción Popular, 2000. p. 63-92.

. Justicia comunitaria y sociedad nacional. Revista Cuarto Intermedio, Cochabamba, Bolívia: Es una revista trimestral de la Compañía de Jesús en Bolivia, p. 80-104, abr. 2010.

BAUMAN, Zygmunt. Modernidade líquida. Rio de Janeiro: Jorge Zahar Editor, 2001.

BRANDT, Hans-Jürgen; FRANCO VALDIVIA, Rocío. Justicia en los Andes: Perú y Ecuador. Normas, valores y procedimientos en la justicia comunitaria: estudio cualitativo en comunidades indígenas y 
campesinas de Ecuador y Perú, Instituto de Defensa Legal (IDL), Lima, Editora, 2007. v. 2.

CAPPELLETTI, Mauro; GARTH, Bryant. Acesso à justiça. Porto Alegre: Editora Fabris, 1988.

CHIVI VARGAS, Idón Moisés. Hacia la descolonización de la justicia. Revista Cuarto Intermedio. Cochabamba, Bolivia: Es una revista trimestral de la Compañía de Jesús en Bolivia, p. 6-22, abr. 2010.

DUSSEL, Enrique. 20 teses de política. Buenos Aires: Consejo Latinoamericano de Ciencias Sociales (CLACSO). São Paulo: Expressão Popular, 2007.

.1492, El encubrimiento del otro, hacia el origen del "mito de la modernidad". La paz. Plural Editores - Facultad de Humanidades y Ciencias de la Educación, 1994. (Colección Academia n. 1).

GROSSI, Paolo. Mitologias jurídicas da modernidade. Tradução de Arno Dal Ri Júnior. Florianópolis: Fundação Boiteux, 2004.

JACCOUD, Mylène. Princípios, tendências e procedimentos que cercam a justiça restaurativa. In: SLAKMON, Catherine; VITTO, Renato Campos Pinto de; PINTO, Renato Sócrates Gomes (Org.) Justiça restaurativa. Brasília: Ministério da Justiça e Programa das Nações Unidas para o Desenvolvimento, 2005. p. 163-188.

KONZEN, Afonso Armando. Justiça restaurativa e ato infracional: desvelando sentidos no itinerário da alteridade. Porto Alegre: Livraria do Advogado editora, 2007.

MASCARO, Alysson Leandro. Filosofia do direito. São Paulo: Editora Atlas, 2010.

MIGNOLO, Walter. Os esplendores e as misérias da ciência: colonialidade, geopolítica do conhecimento e pluri-versalidade epistêmica. In: SANTOS, Boaventura de Sousa. Conhecimento prudente para uma vida decente: um discurso sobre as ciências revisitado. São Paulo: Editora Cortez, 2006. p. 667-709 
SANTAMARÍA, Rosembert Ariza. La justicia comunitaria: aportes a la construcción de un nuevo orden jurídico social. In: LÓPEZ B. Manuel et al. Justicia comunitaria y jueces de paz: las técnicas de la paciencia. Medellín, Colombia: Corporación Región; Red de Justicia Comunitaria, Instituto Popular de Capacitación de la Corporación de Promoción Popular, 2000. p. 34-62.

ROLIM, Marcos. Justiça restaurativa: para além da punição. Disponível em: http:/ / www.comunidadesegura.org/files/active/0/Marcos_Rolim_Justica_Restaurativa.pdf. Acessado em: 26/04/2011. Acesso em: 26 abr. 2011.

. El discurso y el poder: ensayo sobre la sociología de la retórica jurídica. In: RANGEL, Jesús Antonio de La Torre. Pluralismo jurídico: teoría x experiencias. San Luis Potosí/México, 2007. p. 209-233.

Refundación del Estado en América Latina: perspectivas desde una epistemología del Sur. Lima/ Perú: Red Latinoamericana de Antropología Jurídica, 2010.

SABADELL, Ana Lucia; PRUDENTE, Neemias Moretti. Mudança de paradigma: Justiça restaurativa. Disponível em: <www.cesumar.br/ pesquisa/periodicos/index.php/revjuridica/article/view/719/554.>. Acesso em: 26 abr. 2011.

SANTOS, Boaventura de Sousa. Um discurso sobre as ciências. Porto: Edições Afrontamento, 1987.

Democratizar a democracia: os caminhos da democracia participativa. 3. ed. Rio de Janeiro: Civilização Brasileira, 2005.

A gramática do tempo: para uma nova cultura política. São Paulo: Cortez, 2006. v. 4 (Coleção Para um novo sensu comum). tez, 2007.

. Para uma revolução democrática da justiça. São Paulo: Cor-

WOLKMER, Antonio Carlos. Sociedad civil, poder comunitario y acceso democrático a la justicia. Revista El Otro Derecho, ILSA: Bogotá, Colombia, n. 26, p. 135-147, abr. 2002. 
WOLKMER, Antonio Carlos. Pluralismo jurídico: fundamentos de uma nova cultura do direito. 3. ed. São Paulo: Editora Alfa Omega, 2001.

Pluralismo jurídico: os novos caminhos da contemporaneidade. São Paulo: Editora Saraiva, 2010.

ZAPATA, María Lucía. Justicia restaurativa: aproximación conceptual. In: ARDILA, Edgar Amaya et al. ¿A dónde va la justicia en equidad en Colombia?. Medellín/Colombia: Corporación Región, 2006. p. 101-113

. Potenciales y retos restaurativos de la justicia en equidad en Colombia. In: ARDILA, Edgar Amaya; et al. ¿A dónde va la justicia en equidad en Colombia?. Medellín/Colombia: Corporación Región, 2006. p. 279-292.

Artigo recebido em: 04-12-2011

Aprovado para publicação em: 04-01-2012 
